\title{
IMPLIMENTASI MODEL(ASSURE) UNTUK MENINGKATKAN KEAKTIFAN DAN PRESTASI BELAJAR PKn SISWA KELAS IV SD NEGERI 3 BUDI LESTARI KECAMATAN TANJUNG BINTANG TAHUN AJARAN 2015/2016
}

\author{
Ponidi, Dwi Puastuti, Marilin Kristina \\ STMIK Pringsewu \\ Email: Oniponidi@yahoo.com
}

\begin{abstract}
Based on the finding research, the implementation of ASSURE teaching model improves the active learning and achievement in civics of the student of class IV OF SD Negeri 3 Tanjung Bintang Element School. The increase of Students' active learning can be seen from pre- research. It show that 50\% Students are activite. In cycle 1, there are $67 \%$ students who are active. It increaces to $80 \%$ in cycle 2. The civics achievements of the students of class IV OF SD Negeri 3 Budi Lestari Tanjung Bintang Elementary School in the academik years of 2015/2016 is increased. The increase of students achievement can be seen in the pre research from teaching evaluation. It shows that the achievement of $12 \%$ of 25 students is increased. The increase in cycle 1 is $44 \&$ while $88 \%$ is in cycle 2 .
\end{abstract}

Abstrak

Berdasarkan pada pengamatan penelitian, Penerapan pada ASSURE mengajarkan contoh perbaikan pada pembelajaran aktif dan pencapaian ilmu sosial pada siswa kelas IV di SD Negeri 3 Tanjung Bintang (Sekolah Dasar), Pada peningkatan siswa' pembelajaran aktif dapat terlihat dari sebelum penelitian. Terlihat dari 50\% siswa yang aktif. dalam 1 putaran, terdapat $67 \%$ siapa saja siswa yang aktif. Meningkat menjadi $80 \%$ dalam 2 putaran. Pencapaian ilmu sosial pada siswa di kelas IV SD Negeri 3 Budi Lestari Tanjung Bintang (Sekolah Dasar) dalam periode akademik Tahun 2015/2016 adalah Tercapai. Meningkatnya pencapaian pada siswa dapat terlihat pada sebelum penelitian dari evaluasi guru. Terlihat pada pencapaian $12 \%$ dari 25 siswa yang meningkat. Peningkatan pada putaran 1 adalah $44 \&$ terkadang $88 \%$ pada putaran 2.

Kata kunci: pembelajaran aktif, pencapaian pembelajaran,ASSURE MODEL. 


\section{A. PENDAHULUAN}

Profesionalisme guru ditandai dengan pengguasaan empat kompetensi yaitu kepribadian, sosial, pedagogi dan profesional. Keempat kompetensi tersebut mensyaratkan guru agar mempunyai kepribadian yang baik, dapat bersosialisasi dengan berbagai civitas akademika di sekolah, mempunyai kemampuan dalam pengajaran serta menguasai pembelajaran. Profesionalisme guru dapat dibuktikan dengan berbagai prestasi guru baik dalam bidang akademik maupun non akademik. Penggunaan model pembelajaran yang bervariasi dan berbasis teknologi, dapat meningkatan keaktifan siswa dalam mengikuti proses belajar mengajar. Keaktifan siswa yang meningkat, dapat mendorong peningkatan prestasi pembelajaran. Peningkatan prestasi siswa juga dapat diperoleh dengan melibatkan secara langsung siswa dalam pembelajaran, sehingga siswa aktif berinteraksi dengan bahan pelajaran.

Peningkatan prestasi pembelajaran ditekankan pada aspek peningkatan keaktifan menggunakan model pembelajaran. Model yang akan digunakan dalam penelitian tindakan kelas ini adalah model pembelajaran assurre. Model ini sengaja digunakan mengingat karakteristik model pembelajaran asssure sesuai dengan tujuan penelitian yaitu untuk meningkatkan keaktifan siswa dengan mengkaitkan implementasi pembelajaran guna menganalisis kondisi masyarakat.

Keaktifan siswa dalam belajar merupakan persoalan penting dan mendasar yang harus dipahami, disadari dan dikembangkan oleh setiap guru dalam proses pembelajaran. Keaktifan belajar ditandai oleh adanya keterlibatan secara optimal, baik intelektual, emosi dan fisik. Siswa merupakan manusia belajar yang aktif dan selalu ingin tahu. Daya keaktifan yang dimiliki anak secara kodrati itu akan dapat berkembang ke arah yang positif saat lingkungannya memberikan ruang yang baik untuk perkembangan keaktifan itu (Aunurrahman, 2009: 119).

Keaktifan berasal dari kata aktif yang artinya giat bekerja, giat berusaha, mampu bereaksi dan beraksi, sedangkan arti kata keaktifan adalah kesibukan atau kegiatan. Keaktifandapat ditinjau dari dua hal yaitu keaktifan dapat digolongkan menjadi keaktifan jasmani dan keaktifan rohani. Keaktifan jasmani maupun rohani meliputi (1) keaktifan indera yaitu pendengaran, penglihatan, peraba dan lain-lain; (2) keaktifan akal; serta (3) keaktifan ingatan. Keaktifan juga termasuk dalam sumber pembelajaran yang merupakan kombinasi antara suatu teknik dengan sumber lain (Mulyasa, 2008: 158).

Istilah "prestasi" berasal dari bahasa Belanda yaitu prestatie. Kemudian dalam bahasa Indonesia menjadi "prestasi" yang berarti "hasil usaha". Istilah prestasi belajar (achievement) pada umumnya berkenaan dengan aspek pengetahuan. Kata prestasi banyak digunakan dalam berbagai bidang dan kegiatan antara lain dalam kesenian, olah raga, dan pendidikan khususnya pembelajaran (Zaenal Arifin, 2009: 12). Belajar dalam arti luas dapat diartikan sebagai suatuproses yang memungkinkan berubahnya suatu tingkah lakusebagai hasil dari terbentuknya respon utama, dengan syarat bahwa perubahan itu munculnya bukan disebabkan oleh adanya kematangan pada dirinya.
Implikasi prinsip keaktifan dalam proses belajar terlihat dari beberapa kegiatan, yaitu: (a) Memberi kesempatan, peluang seluas-luasnya kepada siswa untuk berkreativitas dalam proses belajarnya; (b) Memberi kesempatan melakukan pengamatan, penyelidikan atau inkuiri dan eksperimen; (c) Memberikan tugas individual dan kelompok melalui kontrol guru; (d) Memberikan pujian verbal dan non verbal terhadap siswa yang memberikan respons terhadap pertanyaan yang diajukan; (e) Menggunakan multi metode dan multi media di dalam pembelajaran (Aunurrahman, 2009: 121).

Kadar pembelajaran dalam pembelajaran aktif dapat diidentifikasikan dari adanya ciri sebagai berikut:

a. Adanya keterlibatan siswa dalam menyusun atau membuat perencanaan, proses belajar mengajar dan evaluasi.

b. Adanya keterlibatan intelektual-emosional siswa baik melalui kegiatan mengalami, menganalisa, berbuat dan pembentukan sikap.

c. Adanya keikutsertaan siswa secara kreatif dalam menciptakan situasi yang cocok untuk berlangsungnya proses belajar mengajar.

d. Guru bertindak sebagai fasilitator dan koordinator kegiatan belajar siswa, bukan sebagai pengajar (instruktur) yang mendominasi kegiatan di kelas.

e. Menggunakan berbagai metode secara bervariasi, alat dan media pengajaran (Muhammad Ali, 2008: 69).

Model assure merupakan model pembelajaran yang bersifat praktis dan mudah untuk digunakan. Model ini dapat diaplikasikan untuk mendesain aktivitas pembelajaran, baik yang bersifat individu maupun kelompok. Langkah analisis karakteristik siswa dan rumusan tujuan diawal akan mempermudahkan guru dalam merancang program pembelajaran atau instructional designer untuk memilih metode, media, dan bahan ajar yang tepat guna menciptakan aktivitas pembelajaran sukses. Hal ini juga berhubungan dengan langkah evaluasi dan revisi yang dapat dimanfaatkan untuk menjamin terciptanya proses pembelajaran yang berkualitas (Benny A. Pribadi, 2011: 5).

Menurut James Russell dan Michael Molenda dalam Benny A. Pribadi (2011: 29) model pembelajaran assure merupakan model pembelajaran yang singkat dari berbagai komponen atau langkah penting yang didalamnya terdapat ciri-ciri antara lain: (1) menganalisis karakter siswa (analyze learning characteristics); (2) menetapkan tujuan pembelajaran (state performance objectives); (3) memilih metode, media dan bahan pelajaran (select methods, media and material); (4) pemanfaatan bahan dan media pembelajaran (Utilize materials); (5) mengaktifkan keterlibatan siswa (requires learner participation); (6) evaluasi dan revisi (evaluation and revision). Model desain pembelajaran ini pada umumnya berisi beberapa langkah sistematik dan sistemik yang di telah diuji coba sebelumnya dalam sebuah situasi pembelajaran. 


\section{PROSEDUR PENELITIAN}

Prosedur penelitian ini berbentuk Penelitian Tindakan Kelas, penjabaran secara lebih rinci disajikan berikut ini:

\section{Rencana Tindakan}

Perencanaan tindakan penelitian merupakan gambaran tentang proses penelitian yang akan dilaksanakan oleh peneliti untuk memecahkan suatu permasalahan yang ada di kelas (Sukardi, 2004: 68). Penelitian Tindakan Kelas pada mata pelajaran Pendidikan Kewarganegaraan dilakukan secara bertahap dalam setiap siklusnya.

Penelitian Tindakan Kelas sering disebut dengan Classroom ActionResearch $(C A R)$. Tiga kata yang membentuk pengertian dari PenelitianTindakan Kelas dapat dijabarkan sebagai berikut: (1) Penelitian yaitu kegiatan mencermati objek, menggunakan aturan metodologi tertentu untuk memperoleh data atau informasi yang bermanfaat untuk meningkatkan mutu dari suatu hal yang menarik minat dan penting bagi peneliti; (2) Tindakan yaitu suatu gerak kegiatan yang sengaja dilakukan dengan tujuan tertentu, yang dalam penelitian ini berbentuk rangkaian siklus kegiatan; (3) Kelas yaitu sekelompok siswa yang dalam waktu yang sama menerima pelajaran yang sama dari seorang guru (Zainal Aqib, 2008: 12).

Raport dalam Rochiati Wiriaatmadja (2005: 11) mengemukakan pengertian tentang Penelitian Tindakan Kelas adalah penelitian untuk membantu seseorang dalam mengatasi secara praktis persoalan yang dihadapi dalam situasi darurat dan membantu pencapaian tujuan ilmu sosial dengan kerjasama dalam kerangka etika yang disepakati bersama. Penelitian Tindakan Kelas juga didefinisikan sebagai penelitian tindakan (action research) yang dilakukan dengan tujuan memperbaiki mutu praktik pembelajaran di kelas. Penelitian Tindakan Kelas memfokuskan pada kelas atau pada proses belajar mengajar yang terjadi di kelas, bukan pada input kelas (silabus, materi dan lain-lain) ataupun output (hasil belajar).

Model penelitian tindakan kelas terdapat empat tahapan yaitu, (1) perencanaan; (2) pelaksanaan; (3) pengamatan; dan (4) refleksi, seperti dapat dilihat pada gambar 1 di halaman berikutnya.

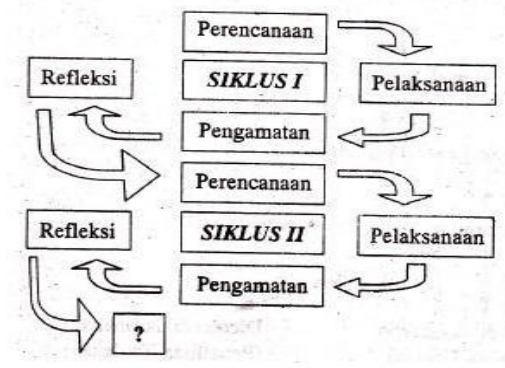

Gambar 1. Model Penelitian Tindakan Kelas (Suharsimi Arikunto, dkk, 2007: 16).

Secara garis besar empat tahap dari penelitian tindakan kelas tersebut adalah:

a. Rencana (Planning)

Rencana merupakan tahapan awal yang harus dilakukan guru sebelum melakukan sesuatu. Diharapkan rencana tersebut berorientasi masa depan, serta fleksibel untuk menerima efek-efek yang tidak terduga. Melalui rencana tersebut secara dini guru dapat mengatasi hambatan. Melalui perencanaan yang baik, guru akan lebih mudah mengatasi kesulitan dan mendorong guru untuk bertindak lebih efektif (Suharsimi Arikunto dkk, 2007: 18)

b. Tindakan (Action)

Tindakan ini merupakan penerapan dari perencanaan yang dapat berupa suatu penerapan model pembelajaran tertentu, dengan tujuan untuk memperbaiki model yang sedang dijalankan. Tindakan tersebut dapat dilakukan oleh guru yang terlibat langsung dalam pelaksanaan suatu model pembelajaran. Hasil dari model pembelajaran tersebut akan dipergunakan untuk penyempurnaan pelaksanaan pembelajaran. Tindakan dalam tahap ini harus hati-hati dan merupakan kegiatan praktis yang terencana. Tahap tindakan ini dapat terjadi jika tindakan tersebut dibantu dan mengacu pada rencana yang rasional dan terukur.

c. Pengamatan (Observation)

Pengamatan ini berfungsi untuk melihat dan mendokumentasikan pengaruh-pengaruh yang diakibatkan oleh tindakan dalam kelas. Hasil pengamatan ini merupakan dasar dilakukannya refleksi sehingga pengamatan harus dapat menceritakan keadaan yang sesungguhnya. Dalam pengamatan, hal-hal yang perlu dicatat oleh peneliti adalah proses dari tindakan, efekefek tindakan, lingkungan dan hambatan yang muncul (Suharsimi Arikunto, dkk, 2007: 18).

d. Refleksi (Reflection)

Refleksi meliputi kegiatan analisis, sintesis, penafsiran, menjelaskan dan menyimpulkan. Hasil dari refleksi adalah diadakannya revisi terhadap perencanaan yang telah dilaksanakan, yang akan dipergunakan untuk memperbaiki kinerja guru pada pertemuan selanjutnya. Penelitian tindakan tidak dapat dilaksanakan dalam sekali pertemuan karena hasil refleksi membutuhkan waktu untuk melakukannya berbagai perencanaan untuk siklus selanjutnya (Depdiknas, 2005: 5).

Tahap penelitian yaitu perencanaan, pelaksanaan, pengamatan dan refleksi merupakan unsur untuk membentuk sebuah siklus, yaitu satu putaran kegiatan beruntun, yang kembali ke langkah semula. Satu siklus adalah dari tahap penyusunan rancangan sampai dengan refleksi, yang tidak lain adalah evaluasi. Apabila dikaitkan dengan "bentuk tindakan", maka yang dimaksud dengan bentuk tindakan adalah siklus tersebut. Bentuk penelitian tindakan tidak pernah merupakan kegiatan tunggal, tetapi selalu berupa rangkaian kegiatan yang akan kembali ke asal, yaitu dalam bentuk siklus (Suharsimi Arikunto, dkk, 2007: 21).

Pada akhir siklus kemudian diadakan evaluasi pembelajaran dengan mengevaluasi hasil keaktifan belajar, efektivitas pembelajaran dan kelemahankelemahan pembelajaran untuk direfleksi. Hasil refleksi tersebut dapat dijadikan pedoman untuk memperbaiki pembelajaran pada siklus berikutnya atau menjadi dasar untuk menghentikan penelitian. Penelitian Tindakan Kelas diakhiri apabila terjadi peningkatan keaktifan siswa pada kategori minimal aktif dan prestasi belajar $75 \%$ di atas nilai kriteria ketuntasan minimal mata pelajaran Pendidikan Kewarganegaraan yaitu 70. 


\section{B. METODE PENELITIAN}

Penelitian ini menggunakan metode deskriptif kuantitaif. Pada penelitian diskriptif kuantitatif, peneliti berusaha menggambarkan kegiatan penelitian yang dilakukan pada objek tertentu secara jelas dan sistematis (Sukardi, 2004: 14). Penelitian deskriptif bertujuan untuk memberikan gambaran tentang suatu hubungan antara dua gejala atau lebih (Irawan Soehartono, 2008: 35).

Metode pengumpulan data dilakukan dengan cara :

\section{Dokumentasi}

Metode dokumentasi yaitu mencari data mengenai berbagai hal yang menyangkut catatan, trankrip, majalah, notulen rapat, agenda, catatan nilai dan sebagainya. Dalam penelitian ini metode dokumentasi diambil dari catatan harian pembelajaran, catatan kolaborator (mitra penelitian), nilai siswa, maupun catatan perkembangan siswa dalam proses pembelajaran.

\section{Observasi}

Observasi yaitu pengamatan dengan menggunakan indera penglihatan. Metode observasi adalah caracara menganalisis danmengadakan pencatatan secara sistematis mengenai tingkah laku dengan melihat atau mengamati individu atau kelompok secara langsung.

\section{Tes}

Metode tes digunakan untuk mengukur kemampuan siswa dalam menguasai materi pelajaran yang telah diberikan oleh guru. Metode tes dalam penelitian ini diberikan secara bertahap, setelah siswa mengikuti metode-metode pengajaran yang disampaikan oleh guru yang bersangkutan.

\section{Analisi Data}

Teknik analisis data yang digunakan dalam penelitian ini adalah deskriptif kuantitatif. Data kuantitatif dianalisis dengan menguraikan fenomena yang terjadi di kelas serta mencari minimum skor mean, maksimal skor dan persentase pada prestasi belajar. Mean mengandung pengertian rata-rata atau jumlah semua angkadibagi oleh banyaknya angka yang dijumlahkan. Rumusnya

$$
M=\frac{? \mathrm{Fx}}{\mathrm{N}}
$$

Keterangan:

$\mathrm{M}=$ Mean

? $\mathrm{fX}=$ jumlah semua angka

$\mathrm{N}$ = Banyaknya angka yang

dijumlahkan

(Saifuddin Azwar, 2010: 33) adalah:

Adapun klasifikasi tingkat partisipasi keaktifan siswa dalam pembelajaran Pendidikan Kewarganegaraan adalah (1) skor $=76=$ sangat aktif; (2) skor $66-75=$ aktif; (3) skor 56-65 = kurang aktif, dan (4) skor $=55$ tidak aktif (Buchory Muh Sukemi, 2006: 42).

\section{PEMBAHASAN}

Pembelajaran dengan menerapkan metode ASSURE merupakan salah satu metode pembelajaran yang digunakan untuk meningkatkan keaktifan dan prestasi siswa kelas IV SD Negeri 3 Budi Lestari. Penerapan model tersebut didasari oleh hasil observasi pendahuluan yang dilakukan oleh kolaborator dan peneliti yang menemukan berbagai hal sehingga dapat menghambat proses pembelajaran. Permasalahan yang ditemukan bahwasanya siswa banyak yang kurang aktif pada saat proses pembelajaran dan nilai siswa masih dibawah KKM. Pengunaan metode ASSURE diterapkan guna melibatkan siswa dalam proses belajar mengajar agar nantinya siswa merasa mudah untuk memahami dan mengingat materi yang disampaikan oleh guru.

Guna mengetahui kegiatan belajar siswa aktif dan memperoleh prestasi, maka harus ada penelitian yang dilakukan dalam kelas. Penelitian tindakan kelas merupakan salah satu strategi untuk meningkatkan kualitas pembelajaran di sekolah. Melalui penelitian tindakan kelas berbagai permasalahan yang menghambat pembelajaran dapat diminimalisasi. Upaya untuk meningkatkan pembelajaran perlu selalu dilaksanakan guru, agar hasil belajar siswa baik kognitif, afektif maupun psikomotor dapat meningkat.

Penerapan model pembelajaran ASSURE dinilai dapat meningkatkan prestasi siswa. Hal ini dapat didasari berdasarkan hasil penilitian yang dilakukan di Kelas IV SD Negeri 3 Budi Lestari Tanjung Bintang. Hasil dari penelitian yang menghasilkan tingkat prestasi dapat dilihat pada tabel berikut ini.

Tabel 1

Hasil Evaluasi Belajar Siswa Kelas IV SD Negeri 3 Budi Lestari Kecamatan Tanjung Bintang Tahun Ajaran 2015/2016 Pra Siklus dan Siklus I

\begin{tabular}{|c|c|c|c|c|}
\hline \multirow[b]{2}{*}{$\begin{array}{l}\mathbf{N} \\
\mathbf{0}\end{array}$} & \multirow[b]{2}{*}{ Uraian } & \multicolumn{2}{|c|}{ Kondisi } & \multirow[b]{2}{*}{$\begin{array}{c}\text { Peningk } \\
\text { atan }\end{array}$} \\
\hline & & $\begin{array}{c}\text { Pra } \\
\text { Siklus }\end{array}$ & Siklus I & \\
\hline 1 & Rata-rata nilai & 64,48 & 68,56 & $4,1 \%$ \\
\hline $\begin{array}{l}2 \\
.\end{array}$ & $\begin{array}{l}\text { Siswa yang melampaui } \\
\text { standar ketuntasan } \\
\text { belajar mata Pelajaran } \\
\text { Pendidikan } \\
\text { Kewarganegaraan }\end{array}$ & 3 siswa & 11 siswa & 8 siswa \\
\hline 3 & $\begin{array}{l}\text { Persentasi siswa yang } \\
\text { telah melampaui } \\
\text { ketuntasan belajar } \\
\text { mata Pelajaran } \\
\text { Pendidikan } \\
\text { Kewarganegaraan }\end{array}$ & $12 \%$ & $44 \%$ & $32 \%$ \\
\hline
\end{tabular}

Sumber: Dokumentasi Hasil Belajar

Berdasarkan tabel 1 tentang hasil belajar pada pelaksanaan siklus I siswa yang telah melampaui Kriteria Ketuntasan Minimum setelah pembelajaran di siklus I naik 8 siswa yaitu dari 3 siswa pada pra siklus menjadi 11 siswa pada siklus I. Persentasi siswa yang telah melampaui Standar Ketuntasan Minimum juga naik sebesar $32 \%$ yaitu dari $12 \%$ saat pra penilitian menjadi $44 \%$ saat siklus I.

Pada saat melakukan observasi pada siklus ke II siswa lebih semangat mengerjakan tugas yang diberikan guru. Kegiatan tersebut akan lebih mempermudahkan siswa dalam mempelajari materi yang akan dibahas sebab siswa secara langsung terlibat dalam permasalahan. Kegiatan inilah yang mendorong siswa untuk dapat menguasai materi pembelajaran dan mempunyai motivasi untuk mempelajari materi 
pembelajaran tersebut. Hasil evaluasi yang diadakan pada siklus II terdapat peningkatan yaitu sebagai berikut:

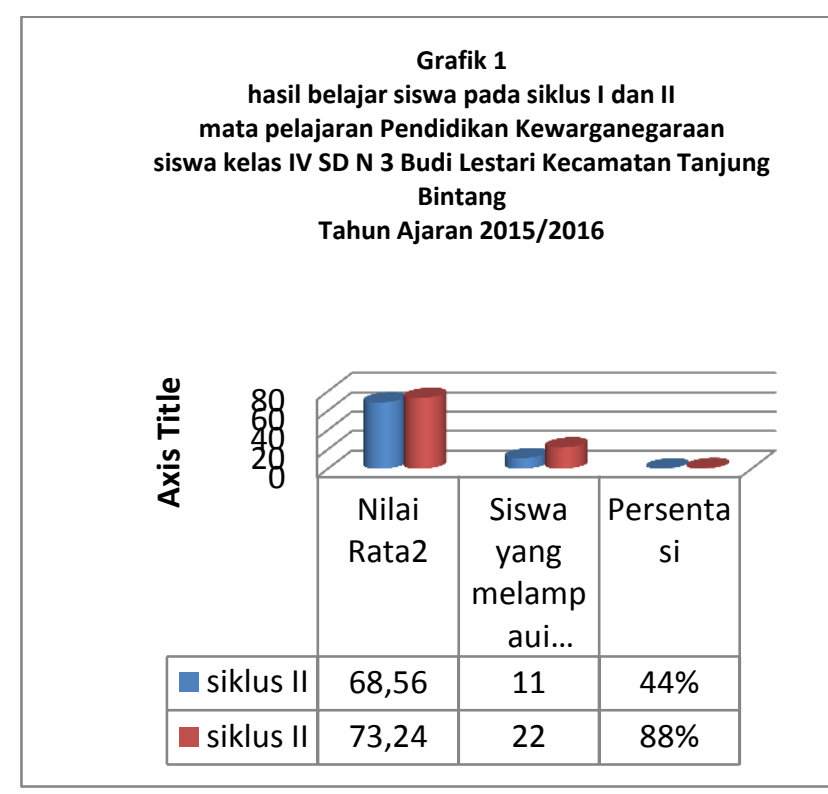

Sumber: Dokumentasi Hasil Belajar

Berdasarkan data hasil belajar siswa pada siklus II maka dapat dicermati bahwa dalam pelaksanaan siklus I ke siklus II terjadi peningkatan prestasi siswa. Siswa yang telah melampaui Standar Ketuntasan Minimum Mata Pelajaran Pendidikan Kewarganegaraan meningkat 11 siswa yaitu dari 11 siswa pada siklus I menjadi 22 siswa pada siklus II. Persentasi siswa yang telah melampaui Kriteria Ketuntasan Minimum meningkat $44 \%$ yaitu dari $44 \%$ pada siklus I menjadi $88 \%$ pada siklus II.

Tabel 2

Hasil Belajar Siswa pada Pra Siklus, Siklus I dan Siklus II dalam Mata Pelajaran Pendidikan

Kewarganegaraan Siswa kelas IV SD Negeri 3 Budi Lestari Kecamatan Tanjung Bintang Tahun Ajaran 2015/2016

\begin{tabular}{|c|c|c|c|}
\hline Kategori & $\begin{array}{c}\text { Nilai } \\
\text { Rata2 }\end{array}$ & $\begin{array}{c}\text { Siswa Yang } \\
\text { Melampaui } \\
\text { SKBMP }\end{array}$ & Persentasi \\
\hline Pra Siklus & 64,48 & 3 & $12 \%$ \\
\hline siklus II & 68,56 & 11 & $44 \%$ \\
\hline siklus II & 73,24 & 22 & $88 \%$ \\
\hline
\end{tabular}

Sumber : Dokumentasi hasil belajar

Berdasarkan hasil penelitian tindakan kelas yang telah dilakukan dengan menerapkan model ASSURE dalam pembelajaran pendidikan kewarganegaraan. Peningkatan prestasi belajar diketahui setelah diadakan penelitian tindakan kelas yang dilakukan dalam proses belajar mengajar. Mata Pelajaran Pendidikan Kewarganegaraan mempunyai Kriteria Ketuntasan Minimum dalam pembelajaran yaitu 70. Pada saat belum diadakan penelitian tindakan kelas terdapat hanya 3 siswa yang telah melampaui Kriteria Ketuntasan Minimum. Siklus I yang dilakukan ternyata dapat menaikkan jumlah siswa yang melampaui Kriteria
Ketuntasan Minimum sebanyak 11 siswa sedangkan untuk siklus II terdapat 22 siswa yang dapat melampaui Kriteria Ketuntasan Minimum. Persentasi siswa yang berada di atas Kriteria Ketuntasan Minimum pada saat belum diadakan.

Peningkatan keaktifan siswa yang dihasilkan dari observasi dengan menggunakan instrumen keaktifan siswa sangat mendukung adanya perubahan. Hasil dari observasi tentang keaktifan dapat dilihat pada data tabel berikut:

Tabel 3

Kriteria Keaktifan Siswa Hasil Siswa Kelas IV SD Negeri 3 Budi Lestari Kecamatan Tanjung Bintang Tahun Ajaran 2015/2016 Pada Pra Siklus, Siklus I dan siklus II

\begin{tabular}{|l|c|c|c|}
\hline \multicolumn{1}{|c|}{ Instrumen } & $\begin{array}{c}\text { Pra } \\
\text { Penelitian }\end{array}$ & $\begin{array}{c}\text { Siklus } \\
\text { I }\end{array}$ & $\begin{array}{c}\text { Siklus } \\
\text { II }\end{array}$ \\
\hline $\begin{array}{l}\text { Perhatian siswa terhadap } \\
\text { penjelasan guru }\end{array}$ & $68 \%$ & $84 \%$ & $100 \%$ \\
\hline Kerjasama dalam kelompok & $68 \%$ & $68 \%$ & $76 \%$ \\
\hline $\begin{array}{l}\text { Kemampuan } \\
\text { mengemukakan pendapat }\end{array}$ & $76 \%$ & $80 \%$ & $76 \%$ \\
\hline $\begin{array}{l}\text { Memberi kesempatan } \\
\text { Kepada teman untuk } \\
\text { berpendapat }\end{array}$ & $32 \%$ & $52 \%$ & $68 \%$ \\
\hline $\begin{array}{l}\text { Mendengarkan pendapat } \\
\text { Siswa }\end{array}$ & $52 \%$ & $76 \%$ & $96 \%$ \\
\hline Memberi gagasan & $52 \%$ & $68 \%$ & $80 \%$ \\
\hline $\begin{array}{l}\text { Membuat perencanaan dan } \\
\text { pembagian tugas }\end{array}$ & $64 \%$ & $32 \%$ & $72 \%$ \\
\hline $\begin{array}{l}\text { Mengambil keputusan } \\
\text { mempertimbangkan } \\
\text { Anggota }\end{array}$ & $50 \%$ & $67 \%$ & $80 \%$ \\
\hline $\begin{array}{l}\text { Memanfaatkan potensi } \\
\text { anggota }\end{array}$ & $76 \%$ & $88 \%$ \\
\hline $\begin{array}{l}\text { Saling membantu siswa } \\
\text { lain }\end{array}$ & $60 \%$ & $72 \%$ \\
\hline rata-rata & $76 \%$ \\
\hline Sumber: Hasil data inst & $64 \%$ & $76 \%$ \\
\hline
\end{tabular}

Sumber: Hasil data instrumen penelitian keaktifan siswa

Berdasarkan hasil observasi bersama kolaborator mendapatkan hasil bahwa tingkat keaktifan siswa dalam pembelajaran pada pra siklus terdapat $50 \%$. Pada siklus I mencapai $67 \%$, sedangan pada siklus II meningkat menjadi $80 \%$.

Hasi observasi keaktifan siswa pada siklus II menghasilkan data tentang peningkatan keaktifan siswa dalam proses pembelajaran. Hasil data pada siklus II dapat dilihat pada tabel berikut: 
Tabel 4

Kriteria Keaktifan Siswa Hasil Siswa Kelas IV

SD Negeri 3 Budi Lestari Kecamatan Tanjung Bintang Tahun Ajaran 2015/2016Siklus I dan Siklus

II

\begin{tabular}{|c|l|c|c|c|c|}
\hline \multirow{2}{*}{ No } & \multirow{2}{*}{ Kategori } & \multicolumn{2}{|c|}{ Siklus I } & \multicolumn{2}{c|}{ Siklus II } \\
\cline { 3 - 5 } & & Jumlah & \multirow{2}{*}{$\%$} & Jumlah & \multirow{2}{*}{$\%$} \\
\cline { 3 - 4 } & & siswa & & siswa & \\
\hline 1. & Tidak Aktif & 2 & $8 \%$ & 0 & $0 \%$ \\
\hline 2. & Kurang Aktif & 9 & $36 \%$ & 3 & $12 \%$ \\
\hline 3. & Aktif & 8 & $32 \%$ & 3 & $12 \%$ \\
\hline 4. & Sangat Aktif & 6 & $24 \%$ & 19 & $76 \%$ \\
\hline
\end{tabular}

Sumber: Hasil data instrumen penelitian keaktifan siswa

Hasil observasi tentang keaktifan siswa mendapatkan hasil bahwa siawa yang tidak aktif berkurang dari 2 siswa (8\%) pada Pra Siklus menjadi 0 siswa (0\%). Siswa yang kurang aktif pada 9 siswa (36\%) dan menjadi 3 siswa (12\%). Kategori yang aktif terdapat 8 siswa (32\%) dan menjadi 3 siswa (12\%). Pada kategori sangat aktif terdapat 6 siswa (24\%) kemudian menjadi 19 siswa $(76 \%)$.

Berdasarkan hasil dari penelitian tindakan kelas yang telah mengukur tentang peningkatan keaktifan siswa pada Pra Siklus, siklus I dan siklus II dapat dijabarkan pada tabel sebagai berikut:

Tabel 5

Kriteria Keaktifan Siswa Hasil Siswa Kelas IV SD Negeri 3 Budi Lestari Kecamatan Tanjung Bintang Tahun Ajaran 2015/2016Pra Siklus, Siklus I dan Siklus II

\begin{tabular}{|c|c|c|c|c|c|c|}
\hline \multirow{2}{*}{ Kategori } & \multicolumn{2}{|c|}{ Pra Siklus } & \multicolumn{2}{c|}{ Siklus I } & \multicolumn{2}{c|}{ Siklus II } \\
\cline { 2 - 7 } & $\mathrm{N}$ & $\%$ & $\mathrm{~N}$ & $\%$ & $\mathrm{~N}$ & $\%$ \\
\hline $\begin{array}{c}\text { Tidak } \\
\text { Aktif }\end{array}$ & 15 & $60 \%$ & 2 & $8 \%$ & 0 & $0 \%$ \\
\hline $\begin{array}{c}\text { Kurang } \\
\text { Aktif }\end{array}$ & 3 & $12 \%$ & 9 & $36 \%$ & 3 & $12 \%$ \\
\hline Aktif & 6 & $24 \%$ & 8 & $32 \%$ & 3 & $12 \%$ \\
\hline $\begin{array}{c}\text { Sangat } \\
\text { Aktif }\end{array}$ & 1 & $4 \%$ & 6 & $24 \%$ & 19 & $76 \%$ \\
\hline
\end{tabular}

Sumber: Hasil data instrumen penelitian keaktifan siswa

Berdasarkan pengelompokan dari ketiga proses penelitian tentang peningkatankeaktifan belajar siswa dalam mata pelajaran Pendidikan Kewarganegaraan mengalami peningkatan. Pada Pra Siklus siswa yang sangat aktif hanya 1 siswa (4\%) menjadi 6 siswa (24\%) dan meningkatan menjadi 7 siswa (28\%). Pada siklus II kategori sangat aktif juga masih mengalamiperubahan yang pada siklus I 6 siswa (24\%) meningkat menjadi 19 siswa $(76 \%)$.

Peningkatan keaktifan siswa hingga pada siklus II merupakan hasil dari penerapan model pembelajaran ASSURE terhadap mata pelajaran Pendidikan Kewarganegaraan. Keberhasilan ini juga merupakan kerjasama antara peneliti dan kolaborator yang selalu mencoba untuk meningkatan kekaktifan siswa pada proses pembelajaran. Berdasarkan hasil penelitin ini, bahwa dengan penerapan model pembelajaran ASSURE tidak hanya mampu meningkatkan prestasi belajar saja, akan tetapi mampu meningkatkan keaktifan siswa dalam mengikuti proses pembelajaran.

\section{PENUTUP \\ 1) KESIMPULAN}

Kesimpulan yang dapat diambil dari penelitian tindakan kelas tentang keaktifan dan prestasi belajar dalam mata pelajaran Pendidikan Kewarganegaraan adalah sebagai berikut:

1. Penerapan model pembelajaran ASSURE pada kelas IV SD Negeri 3 Budi Lestari Kecamatan Tanjung Bintang mampu meningkatkan keaktifan siswa dalam pembelajaran Pendidikan Kewarganegaraan. Peningkatan keaktifan siswa dalam pembelajaran dapat dibuktikan dengan rata-rata pra siklus $50 \%$, meningkat menjadi $67 \%$ pada siklus I dan $80 \%$ pada siklus II.

2. Pembelajaran dengan menerapkan model pembelajaran ASSURE juga dapat meningkatkan prestasi belajar siswa dalam mata pelajaran Pendidikan Kewarganegaraan. Peningkatan prestasi belajar siswa diperoleh dari hasil evaluasi yang dilakukan peniliti dan kolaborator. Hasil tersebut dilihat pada pra siklus prestasi belajar yang mencapai 64, 48, meningkat menjadi 68, 56 pada siklus I, dan 73, 24 pada siklus II. Pada pra siklus siswa yang tuntas mencapai 3 siswa (12\%). Pada siklus I siswa yang tuntas meningkat menjadi 11 siswa yang tuntas (44\%), sedangkan pada siklus II meningkat menjadi 22 siswa yang telah tuntas $(88 \%)$.

3. Penerapan model pembelajaran ASSURE mampu meningkatkan keaktifan dan prestasi belajar siswa kelas IV SD Negeri 3 Budi Lestari Kecamatan Tanjung Bintang Tahun Ajaran 2015/2016 terhadap pembelajaran Pendidikan Kewarganegaraan. Peningkatan ini berdasarkan hasil dari evaluasi yang dilakukan antara peneliti dan kolaborator.

\section{2) SARAN}

Saran yang dapat dikemukakan dalam penelitian dengan penerapan model pembelajaran ASSURE antara lain:

1. Model ASSURE lebih menekankan pada penyelesaian masalah perlu diujicobakan di berbagai pembelajaran tingkat dasar, dengan persyaratan bahwa model masalah yang diberikan lebih disederhanakan. Pembelajaran dengan basis masalah membutuhkan kematangan dalam berpikir siswa, namun dengan penyederhanaan masalah dan media yang menarik akan menjadikan siswa lebih termotivasi untuk menyelesaikannya.

2. Penggunaan model ASSURE bila dikelola secara maksimal dapatmeningkatkan keaktifan dan prestasi belajar. Guru perlu berinovasi menemukan berbagai media pembelajaran yang kreatif sehingga pembelajaran akan lebih menarik. Guru juga akan mendapatkan pengalaman sehingga profesionalisme guru lebih meningkat dalam pembelajaran. 


\section{DAFTAR PUSTAKA}

Aunnurahman. (2009). Belajar dan pembelajaran. Bandung: Alfabeta.

Benny A. Pribadi. (2011). Model assure untuk mendesain pembelajaran sukses. Jakarta: Dian Rakyat.

Buchory Muh Sukemi. (2006). Peningkatan partisipasi siswa dengan model CTLpada pembelajaran Kewarganegaraan Kelas XI SMA Negeri 1 Jetis, Bantul Yogyakarta. Laporan Penelitian Tindakan Kelas tidak diterbitkan.Yogyakarta: Universitas PGRI Yogyakarta.

Depdiknas. (2005). Penelitian tindakan kelas. Jakarta: Depdiknas.

Irawan Soehartono. (2008). Metode penelitian sosial. Bandung: Remaja Rosdakarya.

Muhammad Ali. (2008). Guru dalam proses mengajar. Bandung: Sinar Baru Algensindo.

Mulyasa. (2008). Standar kompetensi dan sertifikasi guru. Bandung: Remaja Rosdakarya.

Rochiati Wiriaatmadja. (2005). Metode penelitian tindakan kelas. Bandung: Rosdakarya.

Saifuddin Azwar. (2010). Tes prestasi belajar. Yogyakarta: Pustaka Pelajar.

Suharsimi Arikunto, dkk. (2007). Penelitian tindakan kelas. Jakarta: Bumi Aksara.

Sukardi. (2004). Metodologi penelitian pendidikan. Jakarta: Bumi Aksara.

Zaenal Arifin. (2009). Evaluasi pembelajaran. Bandung: Remaja Rosdakarya.

Zainal Aqib. (2008). Penelitian tindakan kelas. Bandung: Yrama Widya. 